\title{
The Jewish Presence in China and Japan in the Early Modern Period: A Social Representation
}

\author{
Lucio de Sousa
}

\section{Abbreviations}

AGI

AGN

AGS

ARSI Jap-Sin

$\mathrm{BA}$

$\mathrm{BNC}$

$\mathrm{BNP}$

IAN/TT
Archivo General de Indias. Seville, Spain.

Archivo General de la Nación. Mexico City, Mexico.

Archivo General de Simancas. Simancas, Spain.

Archivum Romanum Societatis Iesu, Japonica-Sinica. Rome, Italy.

Biblioteca da Ajuda. Lisbon, Portugal.

Biblioteca Nazionale Centrale. Rome, Italy.

Biblioteca Nacional. Lisbon, Portugal.

Arquivo Nacional Torre do Tombo. Lisbon, Portugal.

In the course of this work I shall use specific terminology. The word Converso, which was widely used by Spanish and English historiography, and the word Cristão-Novo (New Christian), extensively utilized in Portuguese historiography, have the same meaning. Both refer to Sephardic Jews or descendants of Sephardic Jews who converted/were forced to convert to Christianity (i.e., Catholicism) in Spain and Portugal. These Sephardic Jews, and their descendants,

L. de Sousa $(\square)$

Tokyo University of Foreign Studies, Tokyo, Japan

(C) The Author(s) 2018

M. Perez Garcia and L. de Sousa (eds.), Global History and New

Polycentric Approaches, Palgrave Studies in Comparative Global History, https://doi.org/10.1007/978-981-10-4053-5_9 
are usually divided into two types: those who converted to Christianity and who effectively cut their ties with Judaism; and those who, despite having converted/being forced to convert to Catholicism, secretly practised (some sort of) Judaism. In the Far East, the terms Converso and Cristão-Novo may be confused with Chinese and Japanese neophytes who converted to Catholicism. Documental sources often use these terms. Therefore, I do not believe that it is appropriate to use these terms within an Asian context. Hence, in order to disentangle the different backgrounds of Jewish 'converts' to Christianity, I have chosen to use the term Judeo-converso (Portuguese for a Sephardic Jew forced to convert to Catholicism) for people of Sephardic Jewish origin.

Professor Lucio de Sousa is leading the Board of Advisors of GECEM project. GECEM ('Global Encounters between China and Europe: Trade Networks, Consumption and Cultural Exchanges in Macau and Marseille, 1680-1840') project hosted by the Pablo de Olavide University, UPO (Seville, Spain). The GECEM project is funded by the ERC (European Research Council)-Starting Grant, under the European Union's Horizon 2020 Research and Innovation Programme, ref. 679371, www.gecem.eu. The P.I. (Principal Investigator) is Professor Manuel Perez Garcia (Distinguished Researcher at UPO).

\section{INTRODUCTION}

Judeo-conversos played a very important role in the Atlantic trade carried out by Portugal and Spain in the sixteenth and seventeenth centuries; yet, their presence in China and Japan, barring some specific cases, has remained unknown. The first reason for this absence is due to the fact that the inquisitorial records collected in Goa and covering the Portuguese communities established in these regions have not survived. The second reason is related to the very morphology of this group commonly known as Nação Portuguesa (Portuguese nation: this is how the Portuguese Jews would refer to themselves). Spread over several continents and empires, managing to stay socially connected, the Judeoconversos who participated and created commercial networks as their diaspora extended from the Iberian Peninsula to Macau and Nagasaki also developed various strategies to remain hidden.

This chapter is divided into three sections. The first section will study the formation and establishment of the Judeo-conversos in Macau since the establishment of this Portuguese enclave in China (1557) until the revolt against the Portuguese authorities in 1611. The second section will investigate the Judeo-converso community in Japan and its relationship with the Society of Jesus. The third and final section will examine the cognitive perceptions of Judeo-conversos in China and Japan in the early modern period (c. late fifteenth century to $c$. late eighteenth century). 
The Sephardic presence in Asia between 1498 and 1611 can be divided into four main phases. The first is the opening of the sea route to India by Vasco da Gama (1460-1524) in 1498. Many Jewish descendants participated either in commercial activities or in the Portuguese Diaspora to India. Since at this time the Inquisition had not yet been established in Goa $(1560-1774 ; 1778-1812)$, it is very difficult to identify the Jewish origin of many of these participants.

The second Diaspora starts in around 1548 with the foundation of the Inquisition in Portugal (1536-1821). The Portuguese inquisitorial court, contrary to what had happened with other inquisitorial courts of the Iberian Peninsula, had as its main target the descendants of the Iberian Jews, i.e., the Sephardic Jews of Portuguese and Spanish descent. This event marks a new Diaspora for many Judeo-conversos to Asia, thus forming the first community of Judeo-conversos in India of Iberian origin: the community of Judeo-conversos of Kochi. ${ }^{1}$ These Judeo-conversos established important relations with the Jewish commercial networks in the region, especially with the communities of Hormuz, and with many Sephardic Jewish communities who also settled in North Africa and the Ottoman Empire. The prestige of the Kochi community ended in 1558, when it was accused of having committed several acts against the Catholic faith. The main figures of this community were arrested and, along with their relatives, they were then sent to Lisbon for trial. As can be inferred from the Inquisition archive files, the dismantling of this community was rampant. Many of its members chose essentially three escape routes: Hormuz, the Bay of Bengal and Malacca.

The third dispersion movement began in $1560^{2}$ with the official foundation of the Inquisition Court in Goa as well as with the official settlement of the Portuguese in Macau (1557). Within a few years, this city became a haven not only for Judeo-conversos but also for all merchants and European mercenaries who for some reason wanted to escape the control of the Portuguese authorities in Goa.

The fourth diasporic movement occurred after the fusion of the Portuguese and Castilian crowns (1580-1640). This political event resulted in two important Diasporas: a first one composed of Portuguese Judeoconversos who settled in the neighbouring kingdom of Castile, thus escaping the Portuguese Inquisition, the latter being considered more repressive than its Spanish counterpart ${ }^{3}$; and a second Diaspora also composed of Portuguese Judeo-conversos who chose to move to Spanish America. Many members of the Portuguese community, in Mexico City and Acapulco, initiated significant investments in the trade with China through the Manila 
colony. ${ }^{4}$ This circulation between the Portuguese and Spanish Empires made the inquisitorial persecution against the Judeo-conversos more difficult.

\section{The Sephardic Presence in Macau}

\subsection{The First Community of Sephardic Origin in Macau}

The official European settlement in the Macau peninsula occurred in 1557. This settlement was the culmination of numerous failed attempts to obtain from the Chinese authorities a place where the Portuguese could disembark, wait and prepare their ships for their commercial trips in the area and beyond. The European settlement in this geostrategic place was not the product of mere coincidence as Portuguese traders were looking for a safe haven near Canton where ships could dock for many decades. The Macau Peninsula met all these requirements (Loureiro 1996).

Initially, China had possession of the land and Portugal was the administrative power of the community; yet, gradually it became impossible to disentangle the administrative sovereignty of Macau. Hence, today people tend to say that it was a shared administration, negotiated between the Portuguese and Chinese authorities. Perforce, the local community, consisting of a mixture of nations that considered itself as being Portuguese, was subjugated to various interests. As for the Judeoconversos settled in Macau, they used numerous strategies to survive the religious persecution of the time (de Sousa 2010: 1-11).

In order to rule the local population, the position of Head Captain was created. The latter was the official representative of the Portuguese authorities before the Chinese and Japanese and, simultaneously, was also the highest judicial authority in Macau. Nevertheless, this presence was more symbolic than effective, since in reality the private traders who organized all trade bound for Japan by paying a percentage to the Head Captain were actually in charge of the Portuguese enclave in China (Souza 1986: 18-22; ARSI Jap-Sin 14 II: 341-342).

As for the presence of Judeo-conversos in Macau, prohibiting merchants of Jewish descent from settling in this region dates back to 31 January 1545, when the queen regent Catherine of Portugal (15071578 ) ordered the 13th Governor/4th Viceroy of India, João de Castro (1500-1548), to cancel all previous laws that allowed the Judeo-conversos to travel in the Portuguese Armada to India, declaring that from that moment on, they were to be prevented from travelling to Asia (Andrade, Luíz 1835 [1651]: 422). This law continued with a new edict issued by King Sebastian of Portugal (1554-1578), dated 15 and 20 March 1568, 
in which it was stated that 'any New Christian can go or shall go to the region of India without my permission, signed by me, under penalty of doing the contrary be arrested and lose all their properties, half for those who accuse him and the other part for my Treasury' (Pato 1884, II: 216).

Thus, we can conclude that the presence of Judeo-conversos in Macau, under Portuguese law, was considered illegal and any identified citizen of Jewish descent should be sent to Goa or Lisbon for trial. This judicial context would contribute to the fact that the Judeo-converso community in Macau had to remain hidden and silent during the first two decades of the founding of the city. However, this presence would be unveiled on 15 November 1579, when the Jesuit Francisco de Meneses wrote an important letter to his Superior in Rome, the priest Mercurian, of the intention of the local Judeo-converso community to build a synagogue in Macau: 'a housing and a secret place where they could worship'. This information appears to be genuine, given that the Mandarins of Canton, being consulted by some Portuguese with this request, did not understand the need to build a 'new church', as he could not identify the difference between the Judeo-conversos and the remaining Christian merchants (de Sousa 2010: 72-73).

The same letter also states that in this city lived ' 600 neighbours' of Portuguese origin, which in the sixteenth century meant ' 600 householders,' and half of them, i.e., 300 citizens, were Judeo-conversos who had fled from the Inquisition in Goa. If we associate a family with every Judeo-converso householder (although some could be single), the number of citizens of Jewish ancestry would be even higher. Although I have not found any information regarding the outcome of the negotiations, the answer seems to be in the negative and that the survival of this community in Macau was in danger because of this letter.

Unfortunately, I did not find additional references to the Judeoconversos living in Macau during this time. The Portuguese Inquisition, established in Goa in 1560, focused its activities primarily on India. It did not send any representatives to ascertain the Sephardic presence in Macau (AGN, Inquisición vol. 237: 488f.).

Only in 1583, for the first time in the history of Macau, a Head Captain representing the political and commercial interests of the crown, also represented the interests of the Goa Inquisition. The Head Captain General elected Aires Gonçalves de Miranda, who had a legal warrant issued by the Inquisition to capture and imprison all Judeo-conversos living in Macau and to send them to Goa to be judged. Ironically, this warrant did not prevent the carrack of Aires Gonçalves de Miranda from travelling with Judeo-conversos on their way to China. ${ }^{5}$ 
I am unaware of what type of negotiations had been initiated by the Head Captain General and the local community once the former arrived in the city. However, Head Captain Aires Miranda Gonçalves' plan to imprison all Judeo-conversos did not materialize. The main merchants remained in the city; only those with little or no political or economic clout were captured: Luís Pardo (1582); Francisca Teixeira (1585) and the priest Francisco de Azurara (1585); António Nóbrega (1586); and Pêro Fernandes d'Arias (1587). ${ }^{6}$ Unfortunately, the content of these court files did not survive. Of the accused, only two were indicted for Judaizing (Luís Pardo and Francisca Teixeira). Three of the accused may also be included in one case. When Francisca Teixeira was accused of Judaizing, her husband Pêro Fernandes d'Arias, also a Judeo-converso, bribed the priest Francisco Azurara and received secret information about the legal procedures taken by the Goa Inquisition against his wife.

Upon being discovered, they were both arrested: the priest Francisco de Azurara was sentenced for revealing the inquiries carried out in Macau to the person who was guilty, and Pêro Fernandes d'Arias was sentenced for bribing 'certain people who brought the proofs against his wife for this Holy Inquisition' (Lourenço 2007: 224-227). ${ }^{7}$ As for Francisca, we know that she was born in Macau, daughter of Manuel Teixeira and Inês Gomez, both Portuguese of Jewish descent. His father also had a brother named Estêvão Gomez who lived in India. Three of her sisters were also born in Macau: Leonor da Fonseca (in 1567), who was also captured by the Goa Inquisition in 1594 (IAN/TT, Inquisiçã o de Lisboa, n. 13360); Mécia Leitoa, who married Rui Boto (a Judeoconverso); and Ana Mascarenhas, who married Adrião Almada (a Judeoconverso) and later, a second time, a Portuguese named António Ferreira (a Christian), a householder in Chaul. ${ }^{8}$ There was also a fourth brother named Pedro Teixeira. ${ }^{9}$

Francisca was later sentenced to life imprisonment for Jewish practices. ${ }^{10}$ Her husband Pêro Fernandes d'Arias was released and forced to pay a fine of 11 pardaos. ${ }^{11}$ Unfortunately, Luís Pardo's court files did not survive; hence, it is not possible to reconstruct his social network in Macau.

Except for Francisca and Luís Pardo, none of the remaining Macau Judeo-conversos were captured or tried by the Inquisition; thus, the Portuguese enclave in China remained temporarily impregnable.

As a way to solve the 'Jewish problem' in China and defeat the opposition against the Inquisition in Macau, the Religious Court began to 
restructure the Macau inquisitorial hierarchy and its members, as evidenced by the correspondence between the Inquisitor of Goa and the Holy Office of the General Council of 24 December 1585:

there are many years that neither from China [Macau] nor from Malacca arrives a prisoner, nor denunciation to this table having those regions reputation of having many [Judeo-conversos], where I do not know if I dare claim to be more of service for God and benefit to the souls not to grant to the aforementioned bishops of those places jurisdiction over the Inquisitorial things is at least in China [Macau], but rather their power should be restricted by His Holiness, and these evil places would be remedied and would work much better if Your Reverence send some Inquisitor - if you have two - visit them, and if you do not, you should send a reliable and honest deputy. (Baião 1930, II: 102; Lourenço 2012, I: 218).

In 1586, the new Inquisitor, Tomás Pinto, emphasized again the need to ascertain the purity of blood in Malacca and China:

Your Highness will see how Judaism is quiet, since it is more probable that [Judaism] is concealed because the People of the Nation [i.e., the Portuguese Jews] are spread in some parts of the state [of Portuguese India] like China [Macau], Malacca, Cochin, and the fortresses in the North, where there are many signs that they make their ceremonies and people do not dare denounce them to the vicars because of the abovementioned things. (Baião 1930: 119; Sousa 2004: 24)

This passage clearly shows that although there are indications of Judeo-conversos living in several Portuguese trading posts in India, Southeast Asia and China, the Inquisition found it extremely difficult to penetrate these spaces. Additionally, the Portuguese Christians who had settled in those regions did not denounce the Judeo-conversos. In 1587, despite the impossibility of sending an Inquisitor to Macau, the Religious Court decided to be represented in Macau by sending Captain João Gomes Fayo. ${ }^{12}$ This was the second attempt of the Inquisition to capture Judeo-converso merchants in Macau. Upon his arrival, Fayo presented to the local authorities an ordinance issued by the Goa Inquisition Court to arrest all Judeo-conversos who practised Judaism, promising to give any denouncer half of the confiscated property. As for the other half of the confiscated property, it would go to the Goa Inquisition Treasury (AGN, Inquisición vol. 237: 457f). The justification presented was the 
prohibition of 1568, in which King Sebastian stated that no Judeoconverso could travel to Malacca, China or Japan (AGN, Inquisición 1601, vol. 263, exp. 1U: 140).

In Macau, the arrival of Captain João Gomes Fayo immediately generated a huge controversy among Jewish merchants and a major revolt of the Judeo-conversos traders against the Inquisition (AGN, Inquisición, vol. 237: 457f; de Sousa 2015: 70). The negotiations that followed, and their key players, remain unknown. Also unknown is the outcome of this confrontation (AGN, Inquisición, vol. 237: 457f). However, we can state that the Macau Judeo-conversos won, since no individual of Jewish ancestry from the community was captured or sent to Goa. ${ }^{13}$ This occurrence also demonstrates the cohesion and real importance of this Sephardic community, which had managed to obtain protection from the Christian community against these anti-Jewish sentiments and actions. This episode is also omitted in the letters written by the members of the Society of Jesus to Europe.

Besides the failed attempt by the Inquisition to penetrate Macau, the year 1587 also marked the arrival of an important family of Judeoconversos persecuted by the Lisbon and Goa Inquisitions: Rui Perez and his two sons. ${ }^{14}$

Rui Perez was born in Viseu in the late 1520s or early 1530s to a family of Jewish origin. ${ }^{15}$ Contemporary testimonies claim that he and his family had been persecuted by the Inquisition; hence, he left Europe for India without his wife and with only two children (AGN, Inquisición, vol. 237: 457).

Unfortunately, there are many elements that obscure the true past of the Perez family. In their diaspora this family used many different names to hide its ancestry. For example, Rui Perez also used a second family name: Rui Fernandes (AGN, Inquisición, 1601, vol. 263, exp. IU: 140). His children also changed names during the time they lived in China and Japan. The oldest was known by three different names (António Rodrigues, Francisco Rodrigues and João Rodrigues), whereas the youngest son used the names Manuel Fernandes and Luís Rodrigues (AGN, Inquisicion, 1601, vol. 263, exp. 1U: 137, 138v, 140). This concern in erasing traces that could reveal their true origin, possibly to protect other family members living in Portugal or Asia, suggested a turbulent relationship with the Inquisition.

Being newcomers, and with no ties within the community, the Perez family members were the ideal victims. Therefore, when the 
representative of the Goa Inquisition, Captain João Gomes Fayo, started persecuting them, they did not receive any assistance from the community; as such, they were formally charged for being Jews before the judicial magistrate Damião Gonçalves, who then represented the judicial power of the crown in the city (Braga 1998: 78). Simultaneously, Bishop Leonardo de Sá O.C. (1581-1597), who was living in the city, also decided to persecute them. The eldest son of Perez was the first victim. Arrested on the orders of the Bishop, going by the name António Rodrigues, he negotiated with the authorities his conditional release by paying a bail, only to participate in a Macau-Japan commercial journey. Instead of returning to Macau, he fled to Nagasaki, never to return to China (AGN, Inquisición, vol. 237: 460).

The second victim was Rui Perez himself, who was eventually aided by the most unsuspected person of the entire city, Head Captain Jerónimo Pereira. Pereira, the official representative of the Portuguese crown and the highest authority of the city, hid Rui Perez in the annual trade carrack destined for Japan. It is also through this trail that we catch a glimpse of the Sephardic community living in Nagasaki. The case of the Perez family is an example of how the Macau Judeo-converso community was particularly adverse to the Judeo-conversos persecuted by the Inquisition. Probably the city residents were afraid that these unexpected arrivals could cause major and profound religious investigations by the Inquisition in Goa and decided not to cooperate with or assist the newcomers.

The same would happen to the Judeo-converso António Díaz de Cáceres, who in 1589, in order to recover his fortune (Adler 1896: 29; Cohen 1970: 172-175, 2001: 29; Gitlitz 2002: 69) travelled from the port of Acapulco to the Philippines and Macau (Liebman 1970: 171). He departed on 29 December 1589, as captain of the ship Nuestra Señora de la Concepción, also known by the name San Pedro (AGI, Inquisición, 1596, vol. 159, exp. 1: 83), while his wife, Catalina de Léon y de la Cueva, and his relatives were arrested by the Mexican Inquisition. As for the commercial journey, the historical evidence we have, mainly from Díaz de Cáceres' own diaries, testify that a trading company formed by Díaz de Cáceres (Cohen 1970) and his partner António de los Cobos was purposely created for the realization of this trip. The ship Nuestra Señora de la Concepción/San Pedro was property of the slave merchant Manuel Gil de la Guardia, also a Judeo-converso, future Procurador de Causas de la Real Audiencia de Manila (Attorney 
of Judicial Causes of the Royal Audience of Manila of the Spanish East Indies (AGN, Inquisición, 1597, vol. 160, exp. 1: 74v)).

Díaz de Cáceres would advance the capital and labour as captain, on which he would charge a payment, and Los Cobos invested the capital and half of the merchandise. A third investor, Hernando de la Vega, invested the amount of 4000 pesos and the forth investor, Jorge de Almeida, brother-in-law of Díaz de Cáceres, 1040 pesos (AGI, Inquisición, 1596, vol. 159, exp. 1: 79).

In addition to these investments, the ship, with a crew of 45 sailors, also carried 25 passengers, and each of them had to pay 50 pesos to the captain. The ship would carry silver, wine, olive oil and olives. Arriving in the Philippines, in the port of Cavite, a secondary port, mainly used for smuggling, the vessel needed repairs in the order of 4000 pesos. An official report discovered that half of the goods transported by Díaz de Cáceres were not declared to customs in Acapulco, having been transported illegally. To avoid confiscation and imprisonment, de Cáceres bribed the authorities raising the value of the real damage of the vessel (Uchmany 1989: 164). In order to be able to meet the expenses and increase the profit margin, he decided to travel to Macau. Soon after his arrival in Macau (1590), he was arrested and accused of having entered the port without official permission, thus violating the ordinances of the city and of the Viceroy of Portuguese India prohibiting any commercial contact between Macau and the Philippines. Imprisoned and chained to the wall of a vessel destined for Goa, he prepared for a tragic end at the hands of the Goa Inquisition. Yet, before his departure, he managed to escape.

After Head Captain Aires Gonçalves de Miranda's inquisitorial attempt in 1583 and Captain João Gomes Fayo's second attempt in 1587, the third notable person to represent the Inquisition of Goa was Head Captain Roque de Melo. Having arrived in Macau in 1591 with the objective of capturing Judeo-conversos traders, Roque de Melo failed again to capture any Sephardic merchants settled in Macau or newcomers like António Díaz de Cáceres or the Perez family. In the case of the Perez family, Melo travelled to Nagasaki, where he tried to imprison them. Yet they managed to escape to Hirado with the assistance of the Society of Jesus and from this port they successfully fled to Manila with the help of the ambassador of the Philippines, Pedro González Carvajal, a Portuguese man and with no known Jewish background. The tenacity, adjustment and integration of the Judeo-conversos in Macau contributed 
to the growing opposition to any inquisitorial effort and, because of this, on 17 March 1597, King Philip II, through his representative Pedro Álvares Pereira, sought to intervene in Macau by issuing a new order for the expulsion of the Judeo-conversos settled in the city. The then Viceroy of India, Matias de Albuquerque (1591-1597), was unable to fulfil the order, probably due to pressure exerted by the local mercantile elite. Hence, no direct intervention in Macau occurred (Boyajian 2008: 80).

By the end of the sixteenth century, the Goa Inquisition had only captured three more individuals in Macau. The first victim would be Leonor da Fonseca, a widow, captured in 1594, Francisca Teixeira's sister (the first victim of the Portuguese Inquisition in Macau). Leonor Fonseca's scandalous life in Macau, conducting many love affairs including one with a local priest, would be the main reason for her capture. Alone, abandoned and without any allies, she would eventually die in prison in Goa a few years later (Lourenço 2008: 145-165; 2012).

Nuno Paredes, a merchant, was the second Judeo-converso to be sent to Goa (1595). Unfortunately, the content of his inquisitorial process was destroyed. Hence, I was not able to identify the charges made against him.

The merchant/mercenary Pêro Rodrigues, sent to Goa in 1599, was also accused of Judaizing and of murder. On the latter charge, despite the fact that the court records do not survive, we know that he was a friend of Leonor da Fonseca's family. Despite having been arrested by the Inquisition, he managed to free himself, settling in Japan in 1603 (IAN/TT, Inquisição de Lisboa, n. 4279: 46).

\subsection{The General Pardon of 1605 and the Revolts of the Judeo- Conversos in Macau in 1611}

In Europe, from 1600, the Treasury Council required new measures to be taken against Judeo-conversos. King Philip III (1578-1621), in an attempt to obtain quicker and secured financing, required the major Judeo-conversos of Lisbon, Oporto and Évora to purchase royal pepper at a price set by the crown. The pepper allotment was then sold at exorbitant prices (Boyajian 2008: 88). In 1601, the royal pepper was sold at a price of 52 cruzados per quintal, 20 cruzados above the market price, and the total transaction was 515,529 cruzados (Boyajian 2008: 90). In this process, the Judeo-conversos Jorge Rodrigues Solis and Rodrigo Andrade Évora were the representatives of the main mercantile families 
in the negotiations with the king (Costa 2008: 859-899). This period also coincided with the arrest of many descendants of Jews in Portugal and Portuguese India, as well as in Spanish and Portuguese America. These arrests had a major impact on the Sephardic commercial network, since many of these Iberian Jews and their descendants were in possession of extraordinary wealth at the time and their investments were vital to the stability of commercial circuits. However, at the same time, a period of new negotiations between representatives of the main Iberian Judeo-converso families and the Holy See started. In 1604, after many petitions and donations, the Judeo-conversos obtained the official pardon of the Pope (Codes 2010). Yet this pitfall for the Inquisition could only be successful if it was officially approved by the king, and for that it was necessary to convince the Iberian political elite to publish the papal pardon and bring it into force. Taking advantage of this situation, Francisco de Sandoval y Rojas, Duke of Lerma (1553-1625), using his authority over the king, negotiated the amount of 1.7 million cruzados for the publication of the General Pardon. In fact, the precise amount would be slightly higher, and if we take into account the additional expenses associated with it, it would have been 1.8 million cruzados. The Judeo-conversos of Portugal, Castile and their respective colonies in Asia and the Americas proposed to divide the required amount among themselves. At the head would be Lisbon's mercantile community with 718,377 cruzados, then the remaining communities in Portugal with 736,053 cruzados; the communities of Castile with 200,000 cruzados; New Spain and Brazil together would pay 87,035 cruzados; and finally the communities in Portuguese India and the Far East would pay 75,000 cruzados. The granting of the General Pardon ran from March 1605 until May 1615 (AGS, Secretarías Provinciales, Portugal, libro 1557: 167 fls.). During the period 1605-1610, the amount of capital gathered $72 \%$ (1120,866 cruzados) was invested in the India Run; $12 \%(187,798$ cruzados) went to the royal family and the Duke of Lerma; 11\% (169,085 cruzados) was spent on the Flemish War; and 5\% (71,476 cruzados) on additional expenses. Between 1605 (the date of the General Pardon) and 1610 (the date of its withdrawal), the Iberian crown received from the Judeo-conversos a total of 1,549,225 cruzados. The amount of 150,775 cruzados was not collected. The Castilian community owed the monarch 74,225 cruzados, while the Judeo-conversos of Portuguese India and the Far East communities did not contribute any amount $(75,000$ cruzados $)$. 
It was following these events that the newly appointed Head Captain of Macau (1605-1606), Diogo de Vasconcelos (d. 1640), together with the judicial magistrate, was sent to China in order to conduct a survey of the Judeo-conversos living in the city and charge them a finta. The finta was an extraordinary monetary tax levied by the Portuguese monarchs to Jews and their descendants. These funds were used to sponsor the General Pardon that the Judeo-conversos merchants, although they had committed themselves to support in full, had not paid. This arrival brought significant changes in the community. This tax had been repealed in 1610 by the monarch because, in practical terms, this requirement was illegal. Yet, we should also remember that at the time, trade with Japan had been temporarily interrupted in 1609, only to be re-activated in 1611 by Nuno de Soto Maior (BA, Jesuitas na Ásia, Códice 49-V-3, Francisco Pires S.J., Pontos do que me alembrar: 14v; Charles Boxer 1959: 78-79). Hence, during these three years (16091611), the Macau Judeo-conversos had lost much of their main income.

When the most important private merchants of the city were menaced by the judicial magistrate, on behalf of the Head Captain, to pay the tax, amounting to 4000 cruzados, a considerable sum for the time, the householders of the city, offended by this extortion, organized a rebellion and in several bands pursued the judicial magistrate and Head Captain Diego de Vasconcelos. Immediately, the Judeo-conversos of Macau sent news of what had transpired to Europe. Simultaneously, the judicial magistrate of Macau also sent to Europe a report describing these events, which alas was eventually lost. As a response to this controversial episode, on 26 March 1612, the representative of the king, Bishop Pedro, sent a letter to the Viceroy Jerónimo de Azevedo reprimanding the judicial magistrate's behaviour and stating that the finta tax asked of the most honourable citizens 'do not serve me; and I recommend you, to strictly reprimand the judicial magistrate for the excesses he committed, and also that you order that similar fintas will not be executed without previous knowledge and consideration and whether who are the people of the nation' (Rivara 1875, vol. 6: 930). As for the 4000 cruzados, they were to be delivered and invested in copper and, upon their arrival in Goa, they were to be applied towards the manufacture of artillery pieces (Rivara 1875, vol. 6: 932). As for the judicial magistrate, he should be punished in accordance with his abuses of power (Rivara 1875, vol. 6: 931). Regarding the Judeo-conversos of Macau, they also should be investigated, but with the right to present their own defence, 
which would be compiled in a report and sent to the Court of Goa. (Rivara 1875, vol. 6: 930).

Despite these indications from the crown, the Judeo-conversos of Macau were never listed as such, their names were not sent to Goa, and in the following years the Inquisitions of Goa and Lisbon did not take any measures in order to identify, pursue, arrest or prosecute any Judeoconversos traders hailing from this region.

In conclusion, this extortion attempt by the Portuguese administration of Goa also proves, once again, that the main private merchants of Macau, the notable householders of the city, as they were designated, were in fact a result of the complex phenomenon of the Iberian Jewish Diaspora in Europe and Asia. The constant influx of people of Jewish descent living, passing by and/or doing business in Macau, either for political or commercial reasons, shows a community active not only in terms of commerce but also in terms of diplomacy, able to disarm the Inquisitorial attempts of repression. Unfortunately, we do not have any demographic data from which we can infer their real social and economic contribution to Macau or their adjustment and assimilation processes to Macanese society.

\section{The Sephardic Presence in Japan}

\subsection{Judeo-Conversos and the Society of Jesus in China and Japan}

As for the acceptance of Judeo-conversos by the Society of Jesus, this process was initiated by Father Ignatius of Loyola (1491-1556), founder of the Society. ${ }^{16}$ The mentality of this individual differed radically from the anti-Semitic policies enacted by different religious orders in the Iberian Peninsula during the sixteenth century.

In fact, the Society of Jesus was the only religious congregation where the Judeo-conversos could enter and the Limpieza de sangre (Spanish for 'purity of blood') statutes were not followed (Maryks 2010: 29-31, 76-90). The statutes of Limpieza de sangre were a means of legal discrimination against newly converted people to Christianity in the Iberian Peninsula, or against people suspected of secretly practising their old religions, especially the Marranos (or rather the Anusim), the Conversos, or the New-Christians, in the case of Jewish minorities, and Muslims and their descendants. 
The statutes of Limpieza de sangre varied and could cover one or two generations, or generations even further down the genealogical line. Hence, before any individual had access to administrative positions, military orders and/or religious role in the Portuguese and Spanish Empires, he had to go through different tests proving that he was a Christian with no Jewish or Muslim blood (Rastoin 2007: 14-15).

This segregation policy would be rejected by Loyola, hence the discontent among some of its members, especially among Jesuits hailing from the Iberian Peninsula, a region where the anti-Jewish rhetoric was particularly strong. The first important personality who opposed Loyola was the Portuguese Simão Rodrigues (1510-1579), co-founder of the Society of Jesus and Jesuit Province of Portugal. In 1551, this individual clearly disobeyed his superior and ordered that no Judeo-converso should be admitted to the Jesuit missions in Asia. Francis Xavier (15061552) followed these directives for some time until Loyola, informed of the anti-Semitic policies introduced on his behalf by Simão Rodrigues, revoked the anti-Semitic regulations, again making it clear that the Society of Jesus indeed accepted the descendants of Jews. Unfortunately, this discriminatory attitude ran between 1548 and 1558 (Rastoin 2007: 10-11) until it was overturned by Loyola.

The Judeo-converso acceptance policy by the Society of Jesus began to be widely challenged only after the death of Loyola (1556) and his successor Diego Laínez (1512-1565), also a Judeo-converso.

In 1584, the Congregação Provincial Portuguesa (Portuguese Provincial Congregation) deliberated that the Judeo-conversos should not be accepted by the Society of Jesus. The final blow arrived in 1593, when the Fifth General Congregation of the Jesuits issued an official decree banning all Judeo-conversos from entering the Society of Jesus (Rastoin 2007: 13-15).

And what would then happen to the Judeo-conversos who had been previously admitted? Because of the deeply rooted prejudice against the Portuguese and Spanish Judeo-conversos, they were forced to work outside the Iberian Peninsula and outside Europe, in places like Central and South America, India, China or Japan.

In the case of Japan, the Judeo-conversos entering in the Society of Jesus tended to be from wealthy families and their level of education was also very high. As for this small group of Judeo-conversos that we know, we can divide them into two subgroups: the first subgroup 
includes individuals such as Pedro Gómez (in Japan) and Duarte de Sande (in Macau), who were admitted to the Society of Jesus in Europe, whereas the second group includes names such as Luís de Almeida and Aires Sanches, who were accepted by the Society in Asia. Both were affected by the same prejudice. They had difficulty in ascending the religious hierarchy of their order. If the Judeo-converso Pedro Gómez was appointed Vice-Provincial of Japan (1590-1600), generating animosities among his peers, the Jesuits Luís de Almeida e Aires Sanches had to face major challenges. Being received as brothers by the Society of Jesus, only at the end of their lives were they ordained priests as a reward for the work performed on behalf of the Japanese mission.

A few words highlighting their significant contributions to the Society of Jesus in Japan are necessary here. Pedro Gómez was born in Antequera, Spain in 1535; he had seven siblings. As he himself stated, 'my duty was to study until I joined the Society' (Ruiz-de-Medina 2005: 170). This objective was achieved on 21 December 1553, when Gómez officially joined the Society of Jesus in Alcalá de Henares. At this University, he acquired good training in grammar, the arts, philosophy and theology. His Portuguese experience started in 1555, when he travelled from Cuenca to Coimbra, where he taught until 1559. From 1560 onwards, he travelled between Plasencia, in the Extremadura (Western Spain) and Évora, capital of the Alentejo region in Portugal-roughly $270 \mathrm{~km}$, via Badajoz, on the Spanish-Portuguese border-studying theology and special cases that were useful when converting and giving confession to the Gentiles (Ruiz-de-Medina 2005: 170).

Between 1567 and 1570, Gómez preached in the Portuguese cities of Coimbra and Évora before travelling in 1570 to Angra, on the Island of Terceira, the Azores. On 24 March 1579, Gómez travelled again, this time on the Portuguese Armada to India. This Armada was the first sent to India after the death of King Sebastian of Portugal (1578) (Maldonado 1985).

Gómez arrived in Goa on 9 October 1579 and travelled to Macau in April 1581. On 25 July 1583, he arrived at the port of Nagasaki and became the Superior of the Society of Jesus for the region of Bungo (present-day Oita). With the death of Vice-Provincial Gaspar Coelho (7 May 1590), Gómez was appointed by Father Alessandro Valignano (1539-1606) to succeed him in office, remaining in this post until his death (Ruiz-de-Medina 2005: 171-172). 
In the last stage of his life, Gómez's educational background, along with his Jewish heritage, eventually influenced his writings on forced conversion to Christianity in Japan in the Compendium Catholicae Veritatis, Pars I. Chap 68 (Gómez 1997). On the issue entitled 'quando infideles gentios possunt compelli ad fidem recipiendam. Chapter 68', Gómez explains the two opinions that existed in the Catholic Church: the first defended that it was legitimate to convert the Gentiles by force, but the second opinion stated that forced conversion was illegitimate. In Chapter 68, Gómez believed that conversion was to be performed without the use of force. Though coercion had been used in the Iberian Peninsula and in Japan through vertical conversion (i.e., the baptism of a Daimyo meant the immediate adherence to Christianity by their subordinates), Gómez was against this strategy. Undoubtedly, his thorough knowledge of the religious context of the Judeo-conversos contributed immensely to this opinion.

Luís de Almeida was born in Portugal in 1525, probably in Lisbon, the same city where on 30 March 1546, he was declared fit to practise medicine and surgery by the Cirurgião-Mor (Surgeon-Major, equivalent of today's Chief of Surgery) of the Kingdom of Portugal, Master Gil (de Carvalho 1994: 105-122). Almeida embarked for India on 17 March 1548, devoting himself to trade. The year 1552 marked his first visit to Japan and the year 1553 marked his meeting with the Jesuit Cosme Torres that would influence their decision to join the Society of Jesus and his official acceptance on 15 April 1556 at the port of Funai. His ordination as priest occurred 24 years later, in Macau (6 May 1580). At the end of his life, Almeida was appointed Superior of Amakusa (15811583). He died in Kawachinoura in October 1583 (Yuuki 1989).

This Judeo-converso devoted his life to the implementation of a European system of medicine in Japan (Heynick 2002: 162), building hospitals for the sick, those with then-incurable diseases like leprosy and for the socially deprived.

In addition to donating a large sum of money to the Society of Jesus in Japan, Almeida organized the Society of Jesus as a trading company. This monetary donation to the Society of Jesus is famous since it was considered by the Superior of the Jesuits in China and Japan, Francisco Cabral (1570-1581), and the Visitor of the Society of Jesus, Alessandro Valignano (1574-1606), as the beginning of the religious investment in the Macau-Japan trade (Valignano 1598). That money was invested by 
Luís de Almeida, through his Portuguese trader friends (Schütte 1975: 465; Wicki 1977: 349; de Sousa 2015: 48). This strategy would continue untouched until 1563 , the year in which new economic changes were introduced in the Society of Jesus in Japan. In this year, the Provincial Father António de Quadros (1559-1572) ordered that trade should not be made directly by the Jesuits, but rather through trusted merchants, allies of the Society of Jesus, which should invest the money on their behalf, and upon concluding their sales, they should leave in Japan the necessary amount of money for the support of priests and of the evangelization project. The remaining money should be invested in the trade of the following year (ARSI, Jap-Sin 9 II: 63v). For this purpose, the post of Procurador in Japan was created. The Procurador was the Society's commercial manager who supervised the merchants who invested the Society's funds, the accounting of the investments and profits in the trade between Macau and Japan, plus the amount that should be invested in the following year. In 1563, the first Procurador of Japan, Miguel Vaz, was elected. Vaz represented the financial interests of Portuguese traders and the Society of Jesus until 1582 (Koichirō 1977: 521-534). As a matter of fact, although there had not been any official designation, Almeida was the first Procurador, doing, precisely the same activities that Miguel Vaz later undertook. Even the position and characteristics of the Procurador were modelled on Almeida's experience.

Aires Sanches was probably born in 1527 in Lisbon. ${ }^{17} \mathrm{He}$ was admitted to the Society of Jesus in 1562. Like Luís de Almeida, Sanchez studied medicine, following the Jewish tradition. Yet it is not possible to indicate where he must have acquired the licentia practicandi to practise medicine. Most likely it was the Hospital de Todos os Santos (the Hospital of All Saints), the centre of Jewish medicine in Portugal. In addition to medical studies, Aires Sanches was particularly gifted at writing. This has led some authors to speculate that he must have started studying grammar and the humanities from an early age. Besides these talents, Sanches also excelled in musical training. Despite his Jewish ancestry, as a reward for the work done in the Society of Jesus, he was ordained as a priest in Macau in 1579-1580 (Wicki 1977: 349).

In Japan, Sanches was one of the few Jesuits to actually master the Japanese language. This made him particularly important for the Society of Jesus. He died in Omura in June 1590. 


\subsection{The Community of Sephardic Origin in Nagasaki}

The suspicions of the existence of Judeo-conversos in the Far East appeared immediately after the arrival of the Portuguese in Japan, especially Francisco Zeimoto and Diogo Zeimoto. Francisco was named by the author António Galvão in the work Treaty of Discovery as one of a group of deserters from a Portuguese ship in Siam who sailed to Japan (Galvão 1563), and Diogo Zeimoto was named by the author Fernão Mendes Pinto in the book Pilgrimage as one of the first adventurers who arrived in Japan and in particular for having been the first European to introduce firearms in the region (Pinto 1614). Portuguese and Japanese historiography would give greater credibility to António Galvão's version of the arrival of the first Europeans to Japan; however, it is important to point out something that thus far has not been studied or mentioned. The Zeimoto family name can be traced belonging to Judeo-conversos of Spanish origin who arrived in Portugal after the 1492 expulsion. ${ }^{18}$

Another individual strong suspected of being a Judeo-converso was the most important merchant of Macau, Bartolomeu Landeiro (de Sousa 2010: 63-74; 2015: 49-56). In his autobiographical account, Landeiro reveals that he had helped a Christian Japanese daimyo in the battles against other daimyos who professed other religious beliefs. At the same time, he informs us that he brought a ship with more than 600 tons and that following his arrival and his diplomatic skills, he managed to bring peace to the region. He also points out having built sumptuous churches in Japan where Christian sacraments were administered (de Sousa 2010: 29). To this description we should add some additional information presented by Juan Román Baptista, treasurer of the city of Manila, and Diogo Ferreira, a Portuguese merchant living in Manila. Juan Baptista Román testified that many Portuguese, and particularly the Jesuits, claimed that Landeiro had the possibility of obtaining high profits on the sale of goods in a Japanese port ruled by a non-Christian daimyo. Yet, he obeyed the request of the Jesuits, moving his vessel to another port that belonged to a Christian daimyo, spending a lot of money there and re-establishing Christianity in that region. The merchant Diogo Ferreira adds that Landeiro had built many churches and spent a lot of money on conflicts he had had with enemies in Japan (de Sousa 2010: 23).

However, information about the existence of a small permanent Judeo-converso community in Nagasaki would only arise in the late sixteenth century, with the arrival of the Perez family in Japan. In 1591, the 
Head Captain of the city of Macau, Roque Melo, pursued this family to Nagasaki, who escaped to Hirado and then to Manila. However, Roque de Melo did not dare to interfere with other more powerful Judeoconversos merchants of Nagasaki (de Sousa 2015: 112).

Despite the intervention of the Portuguese Inquisition in Macau, in the case of Japan, until 1598, Judeo-conversos lived freely among the Portuguese and Japanese residents of the city. With the arrival of Bishop Luís Cerqueira in Nagasaki, this situation radically changed. As one of the first steps after his establishment in Nagasaki, the Bishop, upon discovering an ajuntamento ruin (bad group of people), imprisoned five Judeo-conversos, sending two directly to the Inquisition of Goa for trial and three to Macau. This unexpected intervention, according to the letter of the Visitor Alessandro Valignano, generated panic among the Judeo-conversos who remained in the city and feared that they too would turn into future victims of the jurisdiction of Bishop Cerqueira:

It existed also a very bad group of some Portuguese in Japan, which gave [a] bad example to the Japanese, and sent two of them imprisoned to Goa, to the Holy Inquisition, which were New Christians of Jewish descent; and other three (New Christians) living well outrageously, were sent to Macau and with it he (the Bishop) put a strong brake and fear in some other married Portuguese who live here, who up until now did not fear anyone and were getting too much freedom, causing many problems and concerns to ours (the Company's members of Jesus in Japan. (ARSI, Jap-Sin 13-2, 1599-20-02: 213v)

This intervention by the Bishop seems to have been the last, since no further evidence of any Judeo-conversos being sent from Japan to Goa or Macau exists. Interestingly enough, the inquisitorial record of Goa do not make any reference to these prisoners and there is no reference to this episode in the documentation produced in Macau. Unfortunately, we do not know the names of the victims, the charges or the legal outcome. However, we can state that, with respect to the Judeo-converso community that remained in Nagasaki, most of its members established a good relationship with Bishop Cerqueira and with other Jesuits.

As for the Judeo-converso community in Nagasaki, among its finest was the merchant Francisco Rodrigues Pinto (b. 1551), resident of Nagasaki (AGN, Inquisición, 1601, vol. 263, exp. 1U: 139; ARSI, Jap-Sin 31: 209). His Jewish origins were publicly known within the European 
community, something which did not prevent him from testifying on behalf of the Society of Jesus against other Judeo-conversos or maintaining an important alliance with the Bishop of Japan, Luís de Cerqueira (1598-1614), who would characterize Francisco as being 'de mucho hablar, es hombre de bien y que no deixara de hablar verdade en negocio de juramento' ('a very talkative person, an honest man who will speak the truth after taking the oath') (AGN, Inquisición, 1601, vol. 263, exp. 1U: 136).

Even though the exact time when Rodrigues Pinto began living in Nagasaki is unknown, it is known that between 1588 and 1601, he lived in Nagasaki. We also know that he was involved in an important religious controversy in 1598. This controversy had its roots in the San Felipe galleon incident. Departing from Manila bound for Acapulco, the San Felipe galleon ultimately arrived in Japan on 14 October 1596. The diplomatic problem that it generated in the ensuing months between the various religious orders in Japan and with the government of Hideyoshi eventually had an unfortunate outcome: the commodities of the galleon were confiscated by the Japanese authorities and 26 people in Nagasaki were ultimately executed. The Society of Jesus, in order to prove their innocence and given that many books started circulating in Europe accusing them of being the main cause of this tragedy, some of which are dedicated to the highest dignitaries like Pope Clement VIII (BNC, Rome, 9-18-A-4; María 1599a) or Philip III (BNC, Rome: 14-33B-56; María 1599b), eventually sent two reports to Father General Claudio Acquaviva (Biblioteca Nazionale Centrale, Rome, 41-6-D13; Fróis 1607) their version of the events. The Jesuits also performed various inquiries in Japan to investigate what eventually happened with the San Felipe galleon with the intention of exonerating the Society of Jesus' intervention in this sad episode. At the same time, though, many rumours of alleged miracles that occurred at the place of execution of the 26 victims executed in Nagasaki started circulating. To placate this wave of superstition, the Bishop of Japan, Luís de Cerqueira, ordered a special investigation, initiated in September 1598 in Nagasaki, which tried to analyse the supernatural phenomena described.

It is in this context that Francisco Rodrigues Pinto appears as the main eyewitness of one of these miracles published by the Franciscans in the Relacion del martirio de seus frayles descalços de San Francisco de la Santa Provincia de San Gregorio de las Philipinas que padecieron en el puerto de Nangasaqui (Report of the martyrdom of friars of St. Francis 
of the Holy Province of St. Gregory of the Philippines suffered at the port of Nangasaqui). ${ }^{19}$ The Judeo-converso Rodrigues Pinto was present before Bishop Cerqueira on 28 September 1598 to deny the miracle of seeing several columns of fire where the 26 martyrs were executed. This statement has the particularity of containing the signature of Francisco (ARSI, Jap-Sin 31: 209). In the same survey we also have the testimony of Japanese Moro João, which shows that Francisco Rodrigues Pinto's reputation in Nagasaki was not very positive, and tenido en esta tierra asi entre los portugueses como entre los japones por hombre que finge algunas historias (seen on this land among the Portuguese and among the Japanese as a person who invented some stories) (ARSI, Jap-Sin 31:211). The above investigation on these miracles was completed on 3 February 1599, with the final verdict that no miracles had occurred, that the preservation of the bodies of 26 martyrs was due to the cold weather and that the Japanese guards protected the bodies of the martyrs from the carrion birds (Cooper 2003: 177-178).

Another important Sephardic merchant was Manuel Rodrigues/ Manuel Rodrigues Navarro (b. 1547), whom the Bishop said was 'judio de nación, pero hombre de bien y de verdad' ('from the Jewish Nation, but a good and honest man') (AGN, Inquisición, 1601, vol. 263, exp. IU: 136). Rodrigues, who was married, chose to live in Nagasaki (AGN, Inquisición, 1601, vol. 263, exp. 1U: 136), at least between 1588 and 1621. Navarro escaped the Mexican Inquisition, despite having been denounced by a Portuguese merchant named Gaspar Mendes. Through this denunciation, we know that Navarro was born in Beja, Portugal (AGN, Inquisicion, vol. 237: 218). Between 1588 and 1621, despite being settled in Nagasaki, he conducted numerous commercial journeys to Macau, the Philippines and New Spain. For example, in 1592 he departed to Acapulco with the Judeo-converso Antonio Diaz de Caceres (Uchamany 2003: 87) and then to Mexico City, a place where he established a friendship with the Judeo-conversos Manuel Gil de la Guardia and Luis Carvajal. Years later, Carvajal revealed to the Mexican Inquisition that Navarro had also lived in Macau and Manila for some time having unravelled in secret the daily life of the Sephardic community in China:

Manuel Gil de la Guardia who also travelled to China, said that the abovementioned Manuel Rodriguez Navarro was a Jew; thus, he saw and visited him. 
And there he confessed to him, and vice versa, that both were Jews and obeyed to the aforementioned religion. The said Manuel Rodriguez Navarro told him the things the Jews did in China and had no further conversation with the aforementioned Manuel Rodriguez Navarro. (AGN, Inquisicion, 1597, vol. 160, expl: 1)

In 1594 (AGN, Inquisicion, 1597, vol. 160, exp. 1: 74v), Manuel Gil de la Guardia travelled to the Philippines onboard the same galleon used by Manuel Rodriguez Navarro on his return to the Americas (AGN, Inquisicion, 1597, vol. 160, exp. 1: 26). Unlike Navarro, Manuel Gil de la Guardia did not settle in Macau or Nagasaki; instead, he chose to live in Manila. Obviously, the information that Navarro had given him would be of great use to achieve prestige in the city. In Manila, la Guardia gradually ascended the hierarchy of power, reaching the pinnacle of his career when he was appointed Procurador de Causas de la Real Audiencia de Manila (Attorney of Judicial Causes of the Royal Audience of Manila of the Spanish East Indies). Soon after, he became attorney of the sangleyes, term used by the Spanish in the Philippines to classify the Chinese settled in this region, whose interests la Guardia protected by writing petitions against their enemies (AGN, Inquisicion, vol. 237: 176, 177). While la Guardia was captured by the Mexican Inquisition, Navarro managed to escape the inquisitorial persecutions and was never caught by the Portuguese or Spanish Inquisitions. This achievements must have been decisively assisted by the protection of the Bishop of Japan, Luís Cerqueira (AGN, Inquisición, 1610, vol. 903: 240-24lv). After the expulsion of the Jesuits from Japan (1614), Navarro would continue to live in Nagasaki, making many commercial connections. For example, on 11 May 1620, he reached Cavite captaining the boat Santo António (St. Anthony), carrying 101 Japanese sailors (AGN, Indiferente Virreinal, caja-exp. 4154-001; Inquisición, 1620: 15). When questioned by the Inquisition, Navarro stated that he was a full Christian with no Jewish ancestry and that his place of origin was the region of St Thomas in India (AGN, Indiferente Virreinal, caja-exp. 4154-001, Inquisición, 1620: 15), when in fact he lived in Nagasaki on Hirado-Machi Street (Iwao Sei'ichi 1983: 235). His ship was carrying as main commodities flour and fabrics (AGN, Indiferente Virreinal, caja-exp. 4154-001, Inquisición, 1620: 15). A notebook in Japanese with information about Navarro has been preserved with details of another trip from the port of Nagasaki to Manila in 1621. This document reveals in detail the 
goods commercialized: flour, cookies, miso barrels, barrels of salted fish, beans, pork legs, oil pots, iron boxes (crafts) and cotton fabrics (Iwao Sei'ichi 1983: 291-293). From this date onwards, we lose track of Navarro.

There are also references to other Judeo-conversos traders who would live temporarily in Nagasaki and whose relationship with the Society of Jesus and Bishop Luis de Cerqueira was not so close. They were: Afonso Vaez, Francisco Vaez, Diogo Jorge, Vilela Vaz, Pero Nabo, Góis, Paulo Gonçalves and Pero Rodrigues.

The merchant Afonso Vaez was born in Portugal and with his son, Francisco Vaez, a child, fled to Nueva España, where he became very wealthy. Due to religious persecution triggered by the Mexican Inquisition, Afonso Vaez decided to flee to Asia. His departure coincided with the auto-da-fé of 8 December 1596, in which 69 people were victims of the Inquisition. On the eve of the event, in the port of Acapulco, Vaez and his son were recognized by a Portuguese trader who was surprised to see this rich merchant poorly dressed in servant's clothes (AGN, Inquisicion, 1594, vol. 223: 113).

Although he was discovered in Acapulco, Afonso and Francisco Vaez outmanoeuvred the colonial authorities, travelling to Asia and living in Manila for a few years (AGN, Inquisicion, 1594, vol. 223: 113). Religious persecution in the city led them to move on to Nagasaki (on an unknown date). Ironically, the same Portuguese merchant who found them in Acapulco also travelled to Japan and, living in Nagasaki, found and recognized them (AGN, Inquisicion, 1594, vol. 223: 113). It is also in this city that that trader read the Historical Account of the Funeral Obsequies of the Majesty King Philippe II (Relacion historiada de las exeqvias funerales de la Magestad del rey d. Philippo II) (Flórez $1600)^{20}$ and found a reference to Francisco Vaez, in a chapter devoted to fugitives Relaxed in Statue, which has the following passage: 'Francisco Vaez, Portugues, moço soltero por observante de la ley de Moysen ausente relaxado en estatua' ('Francisco Vaez, Portuguese, young unmarried observant of the Law of Moses absent relaxed in statue') (Flórez 1600: $137 \mathrm{v}$ ). Realizing that this was the same person, the merchant secretly revealed all this information to the Bishop, Luís de Cerqueira. The Bishop started a secret inquiry on Vaez and discovered that, meanwhile, both father and son had decided to live in Macau and had then travelled to Goa. The Bishop then sent a letter to the Inquisition of Goa 
to inquire about Vaez and to report the event. On 27 April 1612, this letter was answered in Goa, and being received in July of the same year by the Bishop, the Inquisition asked for more information on the inquisitorial process of Vaez in Mexico before proceeding to arrest and confiscate the property of the family (AGN, Inquisicion, 1594, vol. 223: 113). However, Francis' life changed dramatically with the disappearance of his father Afonso, who died suddenly during a new commercial journey from Macau to Goa. In Goa, Francisco paid his debts and received money of investments; he later decided to return to Macau and then to Japan, where he lived in 1613. In the same year, on 21 March, the Bishop sent the Inquisition of Mexico a new letter asking for more information on Francisco Vaez's trial and about his late father Afonso (AGN, Inquisicion, 1594, vol. 223: 113). On this person we have no further information, nor do we know if any correspondence from the Mexican Inquisition was ever sent to Japan. However, it is unlikely that this has happened due to the events of 1614 (the death of Bishop Luis de Cerqueira in Nagasaki and the Society of Jesus' expulsion from Japan). In this context, we lose track of the merchant Francisco Vaez.

As to the Judeo-converso Paulo Gonçalves, the only information available on the accounts is that he was a merchant and that he lived in Nagasaki (AGN, Inquisición, 1601, vol. 263, exp. 1U: 140v, 141). Is it quite probable that he was a blood relation of the merchant Manuel Gonçalves, also a Nagasaki resident. Gonçalves was involved in the trade between this city and Manila, Siam and Cochinchina, participating in the shuisen trade (Iwao Sei'ichi 1983: 291-293).

Another Judeo-converso merchant living in Japan was Diego Jorge. He was a Lisbon native (b. 1559) (AGN, Inquisición, vol. 237: 473v-474) and at a young age left Portugal for India, becoming part to the Sephardic community that lived in Macau in the early $1580 \mathrm{~s}$. When in 1583 Head Captain Aires Gonçalves de Miranda travelled to Macau aiming to imprison and send all merchants of Jewish descent to Goa, he was one of the persons covered by this law. Even though the Head Captain's mission eventually failed, Diego Jorge became publicly well-known in Macau for being a Judeo-converso (AGN, Inquisición, vol. 237: 488). To escape from the inquisitorial attempts to capture him in Macau, he fled to Nagasaki. Ten years later, in 1593, he fled for the same reasons to Manila, where he again became a potential victim of the Inquisition (AGN, Inquisicion, vol. 237: 488). ${ }^{21}$ Before being captured, he escaped, and after 19 years, we can find Diego Jorge living again in Nagasaki. The merchants Manuel 
Gonçalvez, Jorge Bastião, António da Silva and Francisco Martins together with Diego Jorge will write a Report in 1614 containing various informations in defense of the Society of Jesus in Japan. His Jewish identity is not revealed. This document has the peculiarity of including the signature of Diego Jorge (ARSI, Jap Sin 16I, fols. 134-135v).

As for the Judeo-converso merchant Vilela Vaz, the only known detail is that, like Diego Jorge, after having lived for some time in Nagasaki, he travelled to Manila. Although persecuted by the Inquisition, he also escaped, leaving no clues as to his destination. As for the Judeo-converso Pêro Rodriguez Nabo, we only know that he lived and died in Nagasaki (AGN, Inquisición, 1601, vol. 263, exp. 1U: 141) and that he was a close friend of the Perez family together with the Judeo-conversos Góis, a merchant who travelled to Siam after 1588 (AGN, Inquisición, 1601, vol. 237: 457), and with the merchant Paulo Gonçalves, who also disappeared from the records and who probably fled from Japan (AGN, Inquisición, 1601, vol. 263, exp. 1U: 140v-141).

The last identified Judeo-converso in Nagasaki was Pero Rodrigues, a friend of the Judeo-converso Fonseca family of Macau who, because of inquisitorial persecution, fled from Macau to Japan, where he lived as a merchant (IAN/TT, Inquisição de Lisboa, n. 4279: 46). There are also references to other Judeo-conversos who lived and socialized in Nagasaki; however, their names were not recorded for posterity (AGN, Inquisición, 1601, vol. 263, exp. 1U: 140v).

The presence of Judeo-conversos in Nagasaki remained during the period of religious persecution: e.g., the 20 September 1618, letter of the Jesuit Francisco Vieira seeking to exonerate another Jesuit, Mateus de Couros, of accusations and rumours of leading an immoral life in Nagasaki. Vieira's relevant testimony states that after 1614, de Couros remained in Nagasaki, hid in the house of a Japanese Christian, that this house served as a church for the city's Christians, and that it was frequented by many Japanese women. This house was situated in a residential area; according to him, it was 'rodeada de portugueses maliciosos e cristãos novos' ('surrounded by malicious Portuguese and New Christians [Judeo-conversos]'), and they would feed the rumours about de Couros disrespecting the vow of chastity. Later, both the Portuguese and the Judeo-conversos would state in a survey conducted by the Jesuit Francisco Vieira that the charges against de Couros were 'zombaria e que bem sabem ser tudo mentira' ('a mockery and it was well known to everyone that it was a lie') (ARSI, Jap-Sin 17: 156v).

This would be the last reference to the Judeo-conversos in Nagasaki. From this period onwards, the new challenges posed by the arrival of 
the Dutch and English in the Far East, the expulsion and persecution of the Japanese Christians, as well as the decline of the Portuguese State of India would weaken the presence of the Goa Inquisition in this region. At the same time, the interest of the Society of Jesus in this region was focused on the survival of the mission and of Christianity. Hence, for all these reasons, the Jewish presence was relegated to anonymity.

\section{Cognitive Perceptions of Judeo-Conversos in China and Japan in the Early Modern Period: The Perez Family Case}

Unfortunately, we do not have much information on the presence of Judeo-conversos in Macau and Japan to provide us with details on how a Jewish convert was identified in these communities. So far, the most important documentary source for this period is the inquisitorial trial that was carried out to verify the Perez family, whereby the Inquisition gathered numerous testimonies from Europeans and Japanese Christians, as well as Judeo-conversos. This collection of documents proves that the process of integration of newly arrived Judeo-conversos was not easy or quick; on the contrary, it provoked resistance from local Christian or Judeo-converso communities that had settled there. Throughout this trial, we can also identify and isolate how Judeo-conversos were categorized in China and the rest of the Far East.

Although they were formally considered as Portuguese citizens and were therefore subject to the Catholic Church, were educated in the same places as Christians, lived in the same places and possessed Christian names, the Judeo-conversos in Macau and Nagasaki continued to represent symbolically the ancient religion; hence, they became a target of discrimination. For example, in investigations against the Portuguese Rui Perez, the Judeo-conversos in Nagasaki were categorized by Bishop Luís de Cerqueira as 'hombre de la nación/homem da nação' ('man of the nation') or as 'judio[s] de nacion' ('Jew[s] of the nation'). On the other hand, the markers used by the witnesses of that investigation would be very different. They used the marker 'Cristãos-novos' ('New Christians') rarely. Instead, the markers 'Judeus' ('Jewish') and 'casta de judeus' ('caste of Jews') were mostly used by witnesses (AGN, Inquisición, 1601, vol. 263, exp. 1U: fls 136). Thus, we can conclude that there was no single marker to characterize the Judeo-conversos in China and in Japan; on the contrary, a set of terms were applied applied to them, which reveal a great ambiguity and flexibility. 
Another symbol associated with the Judeo-conversos would be the devil. In Macau, the Perez family were regarded as Jewish and their arrival was seen as the devil's work:

y en macan chicos e grandes lo tenian por judio y de casta de judios y dezian quien diablo los traxo a esta çiudad a este judio no basta los que aca estan (in Macau children and adults thought that he was a Jew and that he belonged to the caste of the Jews and they said: 'What the hell brought this Jew to this city, there are already enough of those living here!') (AGN, Inquisición, vol. 237: 461; de Sousa 2015: 71, 190)

The demonization of the Jew would be accentuated by the physical marker, i.e., the importance of the body also emerges as an important distinguishing factor between Christian and Judeo-conversos in China and Japan. In the case of Perez, skin colour was not used as a form of discrimination; however, other physical markers such as the nose or the feet were used for distinguishing between Judeo-conversos and Christians. For example, the patriarch Perez was identified as a Jew through his nose and big feet (AGN, Inquisición, vol. 237: 458). This racial stereotype had been prevalent in Europe since medieval times; in the case of the Perez family, it was transplanted successfully to the Far East.

Another aspect also used to distinguish between Judeo-conversos and Christians was the different forms of socialization. With the exception of a minority, which collaborates with the Church, the Judeo-conversos in Macau and Nagasaki were considered a distinct group of the remaining Portuguese. Ordinarily, they lived isolated, also communicating with individuals with Jewish ancestry and were subject to discrimination on the streets, being called publicly 'judeus' ('Jews') by Europeans and Japanese. Documents are unanimous in indicating that the Japanese also participated in this discrimination process in Nagasaki (AGN, Inquisición, vol. 237: 443-477):

Todos los de la çiudad los llamavan de judios y tenian por tales assi Japones como portugueses y assi andaban solos que aun los portuguesses que en la dicha çiudad havia no los admitian en sus cassas (All of the city, called them Jews and they were seen as Jews both by the Portuguese and Japanese, and they lived isolated and the Portuguese in this city did not admit them in their homes). (AGN, Inquisición, vol. 237: 446; de Sousa 2015: 174) 
Other distinguishing markers used for this discrimination were the various elements that constituted the Catholic ritual, which was allegedly tainted by ignorance or deliberately by Judeo-conversos. In the case of the Perez family, one of the points used in their public condemnation was that they ate behind closed doors without the company of slaves, thus avoiding the opportunity to observe Jewish rituals. In the case of the Perez patriarch, one of the charges against him was that he ate meat during Lent or, rather, during a time when abstaining from eating meat was mandatory (AGN, Inquisición, 1601, vol. 263, exp. 1U: 139), and the animals that were used for daily feeding were supposedly slaughtered according to Jewish tradition (AGN, Inquisición, vol. 237: 446v-447; de Sousa 2015: 132-133).

In sum, these religious and physical markers converge to show that the echoes of European anti-Semitism successfully travelled to Macau and Nagasaki.

\section{Conclusion}

During this research, I have found that the identified Sephardic members were usually itinerant merchants who for some reason (usually religious persecution) were forced to leave their original communities. Another aspect that stands out in the documents that I have analysed is that these Judeo-conversos were mostly foreign to the Sephardic communities of Macau and Nagasaki. There is little information on these communities and their members, and we do not know the veracity of the events that are extant. They are only referenced when there are drastic political and economic changes, such as dynastic succession (the fusion of the Portuguese and Spanish crowns, 1580-1640), the opening of trade routes with other Asian regions (the Macau-Philippines route) or the collection of taxes (the finta imposed on the Judeo-conversos of Macau).

Another important aspect to note is that this Judeo-converso community concentrated in Macau and Nagasaki organized their commercial networks using not just family members of Jewish origin as agents, but also commercial agents without Jewish ancestry. The arrest and confiscation of property (half for the Inquisition and the other half reverting to the accuser) shows that the Sephardic network required the participation of persons outside the community to prevent their decline. The communities mentioned herein also cannot be characterized as harmonious 
and cohesive. Cases like the Perez family show exactly the opposite to have been the case. The Sephardic communities of Macau and Nagasaki distanced themselves from the Perez family; hence, the ultimate aid came from Christians like the Head Captain of Macau or from the ambassador of the Philippines to Japan. Ironically, some elements of the Sephardic community of Nagasaki (Francisco Rodrigues Pinto and Manuel Rodrigues Navarro) assisted Bishop Luís de Cerqueira and the Inquisition of Mexico in the persecutions. These documents demonstrate that the idea of the Diaspora as an endogamous community, featuring commercial cooperation based on an idea of Jewishness, is not verifiable in Macau as well as in Nagasaki.

We can also conclude that in Macau there was a permanent Judeoconverso community, which established itself in the first decades of the city's foundation. This community, unachievable by the Inquisition in Goa, was gradually revealed by Judeo-converso fugitives seeking shelter in Macau to escape the Inquisition.

This permanent community can be verified through the example of the Manuel Teixeira family. The capture of Francisca Teixeira and, years later, Leonor da Fonseca reveal a Sephardic presence of several generations in Macau.

As for the nomadic community, essentially composed of fugitive merchants either from India or the Americas and the Philippines, this community established important temporary refuge places in Macau and in Nagasaki.

The Sephardic community of Nagasaki was composed of a nomadic community and, at least in the late sixteenth century, there was no fixed Sephardic community dating back several generations, but rather there was a community of merchants brought by the Indian and the Pacific Ocean commercial routes. They arrived at Nagasaki and lived there for short periods of time, only to be expelled when the Macau-Nagasaki trade was closed.

Unfortunately, because of the precariousness of this presence both in Macau and in Nagasaki, dependent on religious, social, economic and political considerations, secrecy was the way they found to ensure their survival. As a result, we are able to catch a glimpse of only a small part of the social and commercial reality of these communities in China and Japan. 


\section{Notes}

1. The first in-depth study of this community was prepared by Walter J. Fischel, subsequently expanded and surpassed by José Alberto da Silva Tavim (Fischel 1962: 33-59; Tavim 1994: 137-261; 1997: 108-117; 2003).

2. This movement is studied by Baião (1930-1949), Tavares (2004) and Lourenço (2007). The Portuguese Inquisition structure has been studied by many authors. I would like to point out here the most recent works by Franco and de Assunção (2004) and Bethencourt (2009).

3. On this topic, see the classic works by Ortiz (1978), Liebman (1970 and 1982 ) and Toro (1982).

4. On this topic, see Hordes (1980), Quiroz (1985) and Splendiani (1997).

5. The case of the merchant Diego/Diogo Jorge (AGN, Inquisición vol. 237: 488).

6. From the Reportório of João Delgado Figueira in Lourenço (2007: 216). BNL, Códice 203, Repertório....

7. Bribery.

8. IAN/TT, Inquisição de Lisboa, n.13360, document not paged, fourth session.

9. IAN/TT, Inquisição de Lisboa, n. 4279. Case of Manuel Fernandes de Araújo in Lourenço, 2012, I: 80.

10. BNP, Códice 203, Reportorio...: 312-312v.

11. BNP, Códice 203, Reportorio...: 502v.

12. João Gomes Fayo was Captain of Cranganor in 1607 (Pato 1880: 17, 77, 132 ).

13. Making a temporal estimate of a journey between Macau and Goa, the return of João Gomes Fayo to Goa occurred after 1588.

14. The Perez family was briefly studied by Eva Alexandra Uchmany. Lúcio de Sousa wrote two biographical works on Rui Perez and the Macau, Nagasaki and Manila Judeo-converso communities in the sixteenth and seventeenth centuries. See 1982: 85-104; de Sousa 2010: 69; 2013: 71-91; 2015; Lourenço 2016: 95-116.

15. Testimony of Francisco (21-10-1596) (AGN, Inquisición, vol. 237: 443v).

16. The first historian to study the presence of Judeo-conversos in the Society of Jesus was Josef Wicki, who wrote an important biographical study of some of these Iberians of Jewish descent. He also compiled an important list with the names of Judeo-conversos who belonged to the Society of Jesus (Wicki 1977: 342-361).

17. The catalogue of Dimissi, defuncti, admissi between 1587-1592 points to Viana as is place of birth. Yet, Wicki believes that he was born in Lisbon. 
18. There is a reference to Zeimoto in the academic research of Maria José Ferro Tavares (Tavares 2010a, b: 185; 2014: 327). See: www.hum.huji. ac.il/upload/_FILE_1379400106.pdf; http://sefarad.revistas.csic.es/ index.php/sefarad/article/viewFile/699/803.

19. Only parts of this book, now lost, are found in the ARSI in Rome (ARSI, Jap-Sin 3 1: 217).

20. http://nrs.harvard.edu/urn-3:FHCL.HOUGH:8140420.

21. Diego was recognized by the Dominican Francisco Sanches de Carvajal, who accused him of being a judeo-converso to the Commissioner of the Holy Office, Fray Diego.

\section{REFERENCES}

Adler, Cyrus. 1896. Trial of Jorge de Almeida by the Inquisition in Mexico. Publications of the American Jewish Society 4: 29-79.

Baião, António. 1930-1949. A Inquisição de Goa: tentativa de história da sua origem, estabelecimento, evolução e extinção. Lisboa: Academia das Ciências.

Baião, António. 1930b. A Inquisição de Goa, Correspondência dos Inquisidores da Índia (1569-1630), vol. II. Coimbra: Imprensa da Universidade.

Bethencourt, Francisco. 2009. The Inquisition: A Global History 1478-1834. Cambridge: Cambridge University Press.

Boxer, Charles. 1959. The Great Ship from Amacon. Annals of Macao and the Old Japan Trade, 1555-1640. Lisbon.

Boyajian, James. 2008/1993. Portuguese Trade in Asia under the Habsburgs, 1580-1640. Baltimore: The Johns Hopkins University Press.

Braga, José Maria. 1998. Jesuitas na Asia. Fundação de Macau: Macau.

Carvalho, José Vaz de. 1994. Luís de Almeida, médico, mercador e missionário no Japão, 1525-1583. In O Século Cristão do Japão. Actas do Colóquio Comemorativo dos 450 anos de Amizade Portugal-Japão, ed. Roberto Carneiro e Artur Teodoro de Matos, 105-122. Lisboa: CEPCEP-IHAM.

Cerqueira, Luís de. 1607. Relatione della Gloriosa Morte fattada sei christiani Christiani Giapponesi per la Fede di Christo, Alli XXV di Genaro M.DC.IV. Madata da Monsignor D. Lodovico Cerquera Vescovo di Giapone. Al Rever. Padre Cláudio Acquaviva Generale della Compagnia di GIESV. Bologna: Per Gio Battista Bellagamba.

Codes, Ana Isabel López-Salazar. 2010. Inquisición Portuguesa y Monarquía Hispánica en tiempos del perdón general de 1605. Lisboa: Edições Colibri.

Cohen, Martin A. 1970. Antonio Díaz de Cáceres: Marrano Adventurer in Colonial Mexico. American Jewish Historical Quarterly 60 (2): 172-175.

Cohen, Martin A. 2001. The martyr Luis de Carvajal. University of New Mexico Press.

Cooper, Michael S.J. 2003. Rodrigues, o Intérprete. Lisbon: Quetzal Editores. 
Costa, Leonor Freire. 2008. El imperio portugués: estamentos y grupos mercantiles. In La monarquía de Felipe III, ed. José Martínez Millán and Maria Antonietta Visceglia, 859-899. Madrid: Mapfre.

De Sousa, Lúcio. 2010. The Early European Presence in China, Japan, the Philippines and Southeast Asia (1555-1590). Macau: Macau Foundation.

De Sousa, Lucio. 2013. A presença Judaica em Macau, Nagasáqui e Manila no século XVI: O caso Ruy Perez. In Revista de Cultura 43.III: 71-91.

De Sousa, Lúcio. 2015. The Jewish Diaspora and the Perez Family Case in China, Japan, the Philippines, and the Americas (16th Century). Macau: Macau Foundation.

Fischel, Walter. 1962. Portuguese Documentation-Cochin in Jewish History: Prolegomena to a History of the Jews in India. Proceedings of the American Academy for Jewish Research 30: 33-59.

Flórez, Dionysio de Ribera. 1600. Relacion historiada de las exeqvias funerales de la Magestad del rey d. Philippo II. nvestro senor hechas por el tribvnal del sancto Officio de la inquisicion desta Nueua España y sus prouincias, y ystas Philippinas : asistiendo solo el licenciado don Alonso de Peralta inquisidor appostolico, y dirigida a su persona por el doctor Dionysio de Ribera Florez, canonigo de la metropolitiana desta ciudad, y consultor del sancto Officio de inquisicion de Mexico. Donde trata de las virtvdes esclarecidas de su Magestad, y transito felicissimo: declarando las figuras, letras, hierogliphicos, empresas, y dinisas, que en el tumulo se pusieron, como persona que lo adorno y compuso, con la inuencio[n] y traça del apparato sumptuoso con que se vistio desde su planta hasta su senecimie[n]to. Mexico: Pedro Balli.

Franco, José Eduardo, and Paulo de Assunção. 2004. Metamorfoses de um polvo: religião e política nos regimentos da Inquisição Portuguesa (séculos XVI-XIX). Lisboa: Prefácio.

Fróis, Luís. 1599. Relatione della Gloriosa morte di XXVI. Posto in Croce per comandamento del Re di Giappone, alli 5. di Febraio 1597, de quali sei furno Religiosi di San Francesco, tre della Compagnia di Giesù, o dicesette Christiani Giaponesi. Mandata dal P. Luigi Frois alli 15. di Marzo, al R. P. Claudio Acquaviva Generali di detta Compagnia. Et fatta in Italiano dal P. Gasparo Stitilli di Campli della medesima Compagnia. Roma: Apresso Luigi Zannetti.

Galvão, António. 1563. Tratado dos Descobrimentos... Lisboa: Casa de João da Barreira.

George Bryan Souza. 1986. The Survival of Empire: Portuguese Trade and Society in China and the South China Sea 1630-1754. Cambridge: Cambridge University Press.

Gitlitz, David Martin. 2002. Secrecy and Deceit. University of New Mexico Press. Gómez, Pedro. 1997. Compendium catholicae veritatis: Compendia. Kirishitan Bunko Library: Sophia University.

Heynick, Frank. 2002. Jews and Medicine. KTAV Publishing House. 
Hordes, Stanley. 1980. The Crypto-Jewish Community of New Spain, 1620-1690. A Collective Biography. Unpublished Ph.D. Thesis. http://nrs.harvard.edu/ urn-3:FHCL.HOUGH:8140420.

Koichirō, Takase. 1976. Unauthorized Commercial Activities by Jesuits. Acta Asiática-Bulletin of the Institute of Eastern Culture 30: 19-33.

Koichirō, Takase. 1977. Kirishitan Jidai no Genkyu. Tokyo: Iwanamishoten.

Liebman, Seymour B. 1970. The Jews in New Spain: Faith, Flame, and the Inquisition. Florida: University of Miami Press.

Liebman, Seymour B. 1982. New World Jewry: 1493-1825. Requiem for the Forgotten: Ktav Pub Inc.

Loureiro, Rui. 1996. Em busca das origens de Macau: antologia documental. Lisboa: Ministério da Educação.

Lourenço, Miguel José Rodrigues. 2007. O Comissariado do Santo Ofício em Macau (1582-1644) A Cidade do Nome de Deus na China e a articulação no distrito da Inquisição de Goa. M.A. Thesis, Universidade de Lisboa.

Lourenço, Miguel José Rodrigues. 2008. Attitudes and Practices of Sociability in Macao at the End of the 16th Century: The Case Against Leonor da Fonseca at the Goa Inquisition (1594). In Bulletin of Portuguese-Japanese Studies 17:145-165.

Lourenço, Miguel Rodrigues. 2012a. Macau, porto seguro para os cristãosnovos? Problemas e métodos sobre a periferia da Inquisição de Goa. Cadernos de Estudos Sefarditas 10-11: 452-499.

Lourenço, Miguel Rodrigues. 2012. Macau e a Inquisição nos séculos XVI e XVII Documentos. 2 vols. Lisboa: ICCM.

Lourenço, Miguel Rodrigues. 2016. Injurious Lexicons: Inquisitorial Testemonies regarding New Christians in Macau, Manila and Nagasaki in the Late Sixteenth Century. In: The Conversos and Moriscos in late medieval Spain and beyond, ed. Kevin Ingram; Juan Ignacio Pulido Serrano, 95-116. Leiden: Brill.

Maldonado, Maria Hermínia (ed.). 1985. Relação das Náos e Armadas da Índia, com os sucessos dellas que se puderam saber, para noticia e instrucção dos curiozos, $e$ amantes da Historia da Índia. Coimbra: Biblioteca Geral da Universidade de Coimbra.

María, Juan de Santa. 1599a. Relatione del Martirio che sei Padri Scalzi di San Francesco, et venti Giaponesi Christiani patirono nel Giapone l'anno 1597. Scritta dal R.P. Fra Gio. Di Danta Maria Provinciale della Província de S. Gioseppe degli Scalzi, \& tradotta dalla lingua Spagnola nella Italiana, per ordine del R. P. Fra Gioseppe di Santa Maria Custode di detta Província per il Capitolo Generale. Et dedicata alla S.ta di N. S. Clemente VIII. Roma: apresso Nicolò Mutij.

María, Juan de Santa. 1599b. Relacion del Martírio que seys Padres Descalços Franciscos, y veynte Iapones Christianos padecieron en Iapon. Hecha por Fr. 
Juan de Santa Maria, Provincial de la provincia de S. Joseph de los Descalços. Dirigida al -Rey nuestro Señor don Felipe III. Con Privilegio. Madrid: Imprenta del Lic. Varez de Castro.

Ortiz, Antonio Domínguez. 1978. Los judeoconversos en España y América. Madrid: Istmo.

Pato, Raymundo Bulhão. 1884. Documentos remettidos da India ou Livro das Monções, Tomo II. Lisboa: Academica Real das Sciencias de Lisboa.

Pinto, Fernão Mendes. 1614. Peregrinaçam.... Lisboa: Pedro Craesbeeck.

Quiroz, Alonso W. 1985. The Expropriation of Portuguese New Christians in Spanish America, 1635-1649. In Ibero-Amerikanisches Archiv, 11:1.

Rastoin, Marc S.J. 2007. "The 'Conversos' in the Society of Jesus or From Windfall to Fall". In Friends on the Way: Jesuits Encounter Contemporary Judaism, ed. S.J. Thomas Michel, 8-27, New York: Fordham University Press.

Rivara, J.H. da Cunha. 1875. Archivo Português Oriental. Goa: Nova-Goa.

Rodrigues, Maria José Tavares.1979. Os Judeus em Portugal no Século XIV. Lisboa: Guimarães.

Ruiz-de-Medina, Juan. 2005. Gómez, Pedro. In Missionação e Missionários na História de Macau, ed. Maria Antónia Espadinha and Leonor Diaz Seabra. Macau: Universidade de Macau.

Schütte, José Franz. 1975. Monumenta Missionum Societatis IESU - Monumenta Historica Japoniae I - Textus Catalogorum Japoniae 1553-1654. Romae: Monumenta Histórica Societatis IESU a Patribus Eiusdem Societatis Edita.

Sei'ichi, Iwao. 1983. Shinhan Shuinsen Bōekishi no Kenkyu [New Edition A Study on the Red Seal Ship Trade] 朱印船貿易史の研究. Yoshikawa Kōbunkan.

Splendiani, Ana María et al. (eds). 1997. Cinquenta años de Inquisición en el Tribunal de Cartagena de Indias, 3 vols. Bogota: Centro Editorial Javeriano.

Tavares, Célia Cristina da Silva. 2004. Jesuitas e Inquisidores em Goa: a cristandade insular (1540-1682). Lisboa: Roma Editora.

Tavares, Maria José Ferro. 2010a. Judeus de Castela em Portugal no final da Idade Média: onomástica e fontes documentais. In Sefarad 74 (2). http:// sefarad.revistas.csic.es/index.php/sefarad/article/viewFile/699/803.

Tavares, Maria José Ferro. 2010b. The Castilian Jews in Portugal: Na Approach to their History. In Hispania Judaica Bulletin 7. www.hum.huji.ac.il/ upload/_FILE_1379400106.pdf.

Tavares, Maria José Ferro. 2014. Judeus de Castela em Portugal no final da Idade Média: onomástica familiar e mobilidade. Sefarad, 74 (1), 89-144, Madrid.

Tavim, José Alberto da Silva. 1994. Os judeus e a expansão portuguesa na Índia durante o séc. XVI. In: Arquivos do Centro Cultural Calouste Gulbenkian, 137-261. Lisboa-Paris: Fundação Calouste Gulbenkian.

Tavim, José Alberto da Silva. 1997. Uma presença portuguesa em torno da "sinagoga nova" de Cochim. In Oceanos, 29: 108-117. 
Tavim, José Alberto da Silva. 2003. Judeus e cristãos-novos de Cochim. História e Memória (1500-1662). Braga: Edições APPACDM Distrital de Braga.

Toro, Alfonso. 1982. Los judios en la Nueva Espana: documentos del siglo XVI, correspondientes al ramo de Inquisicion, Mexico. Archivo General de la Nacion: Fondo de Cultura Economica.

Uchamany, Eva Alexandra. 2003. Encounters between New Spain and the Indian Subcontinent during the colonial Period. In India-Mexico Similarities and Encounters Throughout History, ed. Eva Alexandra Uchamany. New Delhi: Macmillan India.

Uchmany, Eva Alexandra. 1982. Criptojudíos y cristianos nuevos en las Filipinas durante el siglo XVI. In: The Sepharadi and Oriental Jewish Heritage Studies, ed. Issachar Ben'Amid, 85-104. Jerusalem.

Uchmany, Eva Alexandra. 1989. Entre la Nueva Espana y las Filipinas. Experiencia de algunos cristianos nuevos. In: Homenaje a Isabel Kelly, 161-174. México, D.F.: Instituto Nacional de Antropología e Historia.

Valignano, Alessandro. No Date. Adiciones del sumario de Japon. ed. José Luiz Álvarez-Taladriz.

Wicki, Josef. 1977. Die "Cristãos-Novos" in der Indischen Provinz der Gesellschaft Jesu von Ignatius bis Acquaviva. Archivum Historicum Societatis Iesu 46: 342-361.

Yuuki, Diego. 1989. Luis de Almeida, 1525-1583. Médico, caminhante, apóstolo. Macau: Instituto Cultural de Macau.

Open Access This chapter is licensed under the terms of the Creative Commons Attribution 4.0 International License (http://creativecommons.org/licenses/ by $/ 4.0 /$ ), which permits use, sharing, adaptation, distribution and reproduction in any medium or format, as long as you give appropriate credit to the original author(s) and the source, provide a link to the Creative Commons license and indicate if changes were made.

The images or other third party material in this chapter are included in the chapter's Creative Commons license, unless indicated otherwise in a credit line to the material. If material is not included in the chapter's Creative Commons license and your intended use is not permitted by statutory regulation or exceeds the permitted use, you will need to obtain permission directly from the copyright holder.

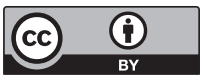

